\title{
A LCC ANALYSIS OF RAINWATER MANAGEMENT VARIANTS
}

\author{
ANALIZA LCC WARIANTÓW ZAGOSPODAROWANIA WÓD DESZCZOWYCH
}

\begin{abstract}
The paper presents results of the Life Cycle Cost (LCC) analysis carried out for several variants of rainfall water management in a newly designed multi-family dwelling house. According to the LCC methodology, calculations were performed for the whole undertaking life cycle with both investment outlays and operation/maintenance costs taken into account. The LCC analysis was carried out, in particular, for a variant assuming that the rainwater collected from the roof will be entirely discharged to the sewage system. On the other hand, the second variant provided for replacement of traditional building roof with a green one. Facilities of that type, thanks to their retention properties, may delay runoff of rainwater and reduce the overall quantity of water discharged from roof surface and therefore can be classified as Sustainable Urban Drainage Systems. In the third case considered, rainwater is to be utilised in the building. It was assumed that precipitation water will be stored in a tank and used in the sanitary water supply system for flushing toilets, thus reducing the overall tap water purchase costs.
\end{abstract}

Keywords: rainwater, LCC analysis, sustainable development

\section{Introduction}

Rainwater represents a component of resources that in the whole of natural circulation of water in the nature ensures renewability of surface and underground waters. For that reason, precipitation waters should be protected from degradation and properly managed, especially in highly urbanized areas where, as a result of continuous increase of surface sealing, substantial majority of rainwater is discharged idly to receiving waters via sewage systems.

A traditional precipitation water management model used commonly in the past consisted in possibly fast and effective interception of the runoff and channeling it to the receiving water. Such model can result in occurrence of many disadvantageous effects in the natural environment such as: lowering the groundwater table; soil over-desiccation; intensification of flood phenomena in watercourses; pollution of and morphological changes in rivers; and disturbances in water ecosystems. Moreover, during intensive precipitation

\footnotetext{
${ }^{1}$ Department of Infrastructure and Sustainable Development, Rzeszow University of Technology, al. Powstańców Warszawy 12,35-959 Rzeszów, Poland, email: daniels@prz.edu.pl

${ }^{2}$ Department of Environmental Engineering, Technical University of Kosice, Vysokoškolská 4, 04200 Košice, Slovakia, email: martina.zelenakova@tuke.sk

*Corresponding author: stec_aga@prz.edu.pl
} 
periods, excessive inflows of stormwater to sewage systems can cause hydraulic overloading, resulting frequently in inundation of land and buildings and impediments in public transport.

To stop and prevent these negative changes in the environment, a change in attitude and proper approach is required to the precipitation water management through basing the related activities on sustainable rainwater management policies.

The EU Water Framework Directive provided obligation to manage precipitation waters in line with the sustainable development philosophy [1]. According to provisions of the act, rainwater should be retained, either fully or in a part, at location where the precipitation occurred through the use of natural surface and underground retention processes and water infiltration into the ground. Poland has its own regulatory act entitled 'Water Law' [2] according to which water resources must be dealt with in a well-balanced and comprehensive manner with water quantity and quality taken into account in a way protecting water ecosystems from deterioration, which cannot be achieved without sustainable precipitation water management.

This paper presents an analysis of three selected rainwater management variants for a multi-family dwelling house located in Rzeszow (Poland). From the point of view of the building's user, costs are considered as the most important factors when decisions on selection of the rainwater management method are to be taken. As the subject of the study is a newly erected building, the Life Cycle Cost (LCC) methodology has been adopted as a financial analysis tool.

The analysis was carried out for the following variants of the precipitation water management method to be adopted in the building:

- disposal of precipitation water from the building roof to sewage system - Variant I;

- retention of precipitation water on the building's green roof - Variant II;

- utilization of precipitation water for flushing toilets in the building - Variant III.

\section{A review of studies on rainwater management methods}

Implementation of a sustainable water discharging system involves usually construction of devices and facilities for retention and infiltration of rainwater into the ground. Typically used solutions include: water dispersing boxes and chambers; sink basins, ditches and wells; and reservoirs. However, the use of facilities of that type in urban conditions is restricted for many reasons related mainly to shortage of free space required for construction of these structures. A solution to the problem can be systems for harvesting and commercial utilization of rainwater as well as the so-called green roofs. For that reason, the analysis was carried out for the three above-mentioned precipitation water management variants and a review of research results obtained in this area was performed.

In the case of the traditional precipitation water management model, building owners in many countries of the world are obliged to pay tariff charges for disposal of rainwater to local sewage systems. Typically, tariff rates include costs of operation and maintenance of the sewerage network and water treatment plants and costs related to development and modernization of these facilities.

In many North American cities, fees for precipitation water are charged for more than 20 years now. Tariff charges are calculated based on a determined equivalent unit called Equivalent Stormwater Unit, Equivalent Runoff Unit, or Equivalent Residential Unit, 
depending on the state [3-9]. However, regardless of name of the conversion unit, the concept behind the charging system is the same in each state. It refers to an averaged value calculated based on the impervious surface area measured on selected land plots. In the City of Pittsburgh, for example, property owners were charged 3.56 \$ per month and Equivalent Residential Unit (1 ERU = 3.106 sq.ft.) [7]. On the other hand, stormwater fee depends on the land development type. Owners of residential buildings pay their stormwater fee calculated based on the impervious surface on the parcel that in the year 2011 amounted to 25-70 \$ per annum. For multi-family dwelling houses, industrial facilities and public buildings, the annual fee per Equivalent Residential Unit (1 ERU $=1.425$ sq.ft.) amounts to $45 \$$ [9]. Also in the City of Nashville, fee rates for discharging precipitation water are different for residential and non-residential areas. The fee is based on the impervious surface area and ranges from 1.5-4.5 $\$$ for dwelling houses to $10-400 \$$ for other structures per sq.ft. and month [8].

Also in European countries, stormwater utility fees are charged for many years now. In most of Germany's Lands, the fees are calculated based on the impervious surface area. Each year, the fee rate is determined in euros per square meter of the so-called reduced catchment area (verified sealed surface area multiplied by the runoff coefficient determined by the local sewage system manager). The rate in the City of Hemmingen is $0.27 / \mathrm{m}^{2}$, compared with $0.68 / \mathrm{m}^{2}$ in Hannover [10].

Another method of charging stormwater utility fees commonly applied in Germany is the so-called basic and stepwise tabular fee. The basic tabular fee is an amount determined in euros and payable for each $\mathrm{X} \mathrm{m}^{2}$ of the sealed surface and part thereof. For instance, in the town of Detmold the fee amounts to 11.25 for each $15 \mathrm{~m}^{2}$ or part thereof [11]. On the other hand, tabular stepwise fee is charged as a sum of a basic fee and an additional fee for each subsequent area of impervious surface or part thereof. For example, in the town of Kiel, the fee amounts to 33 for the first $60 \mathrm{~m}^{2}$ and then 11 for each subsequent $20 \mathrm{~m}^{2}$ or part thereof [12].

In Denmark, the stormwater fee is a $40 \%$ component of the total cost incurred by citizens in the framework of the so-called drainage fees [13].

In Poland, the issue of precipitation water fees is still new and hardly known beyond the circle of water and wastewater specialists, yet arousing controversies and objections among the general public. To date, only a dozen or so towns have decided to charge the fees, including Pila, Gniezno, Ostrow Wielkopolski, Kluczbork, Opole, Nysa, Siedlce, Kielce, and Tarnow.

In the developed countries, a long-standing practice results in awareness and acceptance of the fees charged for maintenance of drainage systems in highly urbanized areas. To a large extent, this is an effect of well-managed information campaigns and implementation of a system of discounts for residents owing local rainwater management facilities. For instance, in German cities of Cologne and Mannheim owners of buildings with green roofs are charged only a half of regular fee for discharging stormwater to sewage systems [14].

Green roofs, for their retention properties, are classified as the so-called Sustainable Urban Drainage Systems. Utilization of such structures allowing to reduce energy and water consumption is recommended by the European Union [15].

Discussions on profitability of green roofs are held for many years. Lee has analyzed the life cycle costs for a building in the state of Oregon provided with a traditional roof or 
with an extensive green roof. In the analyses, he assumed that the structure's life will be 60 years. Results obtained by the author indicate that a traditional roof is by $7 \%$ less expensive in the analyzed period [16]. In turn, Carter and Keeler have carried out a life cycle cost analysis for a green roof constructed in 2002 at a university campus in the state of Georgia. The authors compared results of the analysis for the assumed structure's operation period of 40 years with costs corresponding to traditional roofing. The Net Present Value (NPV) for the green roof in question was by $10 \div 14 \%$ higher that NPV of a conventional roof [17]. However, studies taking into account primarily the costs resulting from environmental benefits of green roofs, confirmed purposiveness of their use $[18,19]$.

Numerous research projects prove that green roofs can delay the runoff from roof surfaces and reduce its total volume. In view of the fact that the rainwater outflow rate is affected by many factors related to local climate, precipitation profile, and the structure of the roof itself, results of various studies differ from each other in many cases. This is the case especially when the roof retentiveness is determined; its value, according to Getter et al, can be as high as $80.8 \%$ [20], compared with $45 \%$ obtained by DeNardo et al for the same roof [21]. In research work on this subject it is essential that such circumstances will be taken into account as facility location and the related precipitation profile typical for the area, especially precipitation total distribution in time, frequency of occurrence, and intensity. For example, a roof located in Hamburg area (with annual precipitation total amounting to $820 \mathrm{~mm}$ ) can retain about $60 \%$ rainwater [22], while a green roof of the same type in Berlin (with annual rainfall total of $500 \mathrm{~mm}$ ) will show retentiveness amounting to $75 \%$ [23]. For that reason, when the roof retention capacity is being determined, it is inadvisable to base on results obtained in other countries where different climatic conditions prevail; such data may be used only for comparative purposes.

The studies referred to herein take into account not only the green roof thickness and layered structure and their effect on water retention, but also inclination of the roof slope. German researchers $[22,24]$ arrived at the conclusion that inclination has no effect on the amount of rainwater retained. This is however contrary to results obtained by other scientist who analyzed roofs with different slope gradients $[20,25,26]$. VanWoert et al analyzed the effect of roof slope inclination versus the rainfall intensity. For not very intensive rains, the examined green roofs with inclination of 2 and $6.5 \%$, retained 98 and $90 \%$ rainwater, respectively. In the case of very intense rains, however, the author did not observe any difference between retentiveness measurement results taken for the two analyzed roofs [25]. Getter et al examined 12 extensive green roofs with slopes of 2, 7, 15 and $25 \%$ in their experimental station. On the grounds of two-year observations they have arrived at the conclusion that the retention value decreases with increasing roof slope inclination [20].

A significant portion of water falling onto a green roof surface is subject to absorption by the roof substrate and vegetation, and then by means of evaporation and transpiration it can be returned back to the atmosphere. Kolb has published results of his research work showing that $45 \%$ of total precipitation can be recycled this way [27]. Bengtsson has carried out studies on an extensive green roof established in Malmo in southern Sweden. On the grounds of the performed water balance the author concluded that the annual runoff of precipitation water from the roof in question could be reduced as a result of evaporation by as much as up to $64 \%$ [28]. Kohler obtained similar results in his own studies. Green roofs with vegetation layer 5 to $10 \mathrm{~cm}$ thick are capable to reduce, by means of evaporation, the total annual runoff by as much as $60 \div 79 \%$ [29]. 
In Poland's scientific centers, issues concerning green roof retentiveness evaluation remained outside the mainstream of interest. Results of studies carried out on experimental setups at the Natural University of Wroclaw for two types of roofs published in [30] proved that the average retaining capacity of the tested roof solutions amounted to about $89 \%$. Reference [31] also presents results of research work on possibility of temporary storage of precipitation water on roofs covered with a vegetation layer. In this case, the object of investigation consisted in green roof developed on floor slabs of a multi-space car park in Wroclaw.

Simulation research studies concerning possibility to reduce rainwater runoff from green roofs were carried by Stec and Hypiak [32]. The paper presents an analysis of rainwater runoff volume from sealed roofs and green roofs with different substrate layer thickness. Simulations with the use of real-life precipitation data were carried out with the use of Storm Water Management Model program. The studies have confirmed the effect of roof layer thickness on the degree of reduction of water outflow from roof surface.

Apart from reducing the total runoff, green roofs additionally slow down the outflow of precipitation water to the sewage system which in turn can protect the system from hydraulic overloading. Depending on the roof type and design, the related delay can range from $95 \mathrm{~min}$ [33] to as much as 4-5 h [34, 35]. Liu, examining the effect of a green roof on rainwater runoff from the roof slope observed that the actual precipitation with intensity of $2.8 \mathrm{~mm} / \mathrm{h}$ was reduced to a runoff with intensity of $0.5 \mathrm{~mm} / \mathrm{h}$ [33]. Also Fioretti et al, analyzing the effect of Mediterranean climate on a green roof installed on one of the buildings at the University of Genoa in Italy, have observed a delay of water runoff from the roof ranging from $71 \mathrm{~min}$ to $306 \mathrm{~min}$. In the course of the same research project carried out in the period September-December 2008, they have obtained results demonstrating a strong dependence of green roof retentiveness on duration of dry period preceding occurrence of precipitation. Whenever the period was shorter than $96 \mathrm{~h}$, the retention capacity was less than $20 \%$, while for rainfalls separated by less than $12 \mathrm{~h}$, the precipitation water runoff reduction was close to zero [35].

By inhibiting the runoff and reducing precipitation water volume, green roofs can mitigate unfavorable phenomena accompanying stormwater runoff from highly urbanized areas, especially urban floods and sewage system overloads. Deutsch et al have estimated that if $20 \%$ roofs of buildings in Washington were covered with vegetation, they would be capable to store annually 958 million liters rainwater on average [36]. Similarly, Peck calculated that if $6 \%$ of buildings in Toronto were provided with green roofs, they would retain the same amount of precipitation water that is currently discharged to retention channels constructed at the cost of 60 million dollars [37].

The benefits resulting from efficient precipitation water management represent only a small portion of advantages connected with establishment of green roofs that, apart from their ecological and hydrological function, have a positive effect on the standard of living in towns through their landscape amenity and practical functions.

Numerous studies prove that green roofs can purify air by removing contaminants such as dusts [38], sulfur dioxide [39] and nitrogen dioxide [40]. Peck and Kuhn demonstrate that one square meter of a green roof is capable to remove $0.2 \mathrm{~kg}$ dust from air annually [38]. Yok Tan and Sia have tested the possibility to reduce sulfur dioxide content in air by green roofs in Singapore. They report $37 \%$ reduction of concentration of the compound in direct vicinity of the examined roof [39]. Further, Clark et al have estimated that providing 
$20 \%$ industrial and commercial buildings in Detroit with extensive green roofs would result in removing more than $800 \mathrm{Mg}$ of nitrogen dioxide annually [40].

Installation of green roofs contribute also to a decrease of consumption of energy used for heating and cooling and thus reduce the overall electric power demand in buildings. The effect is most noticeable in the summer season. Depending on ambient temperature, heatinsulating properties of green roofs can result in a decrease of temperature inside buildings by $3 \div 4{ }^{\circ} \mathrm{C}$ [41]. Connelly and Liu have measured heat transfer rate through a traditional roofing and a green roof. In the heatwave season, they have observed heat flow rates of 2.63 and $0.7 \mathrm{~kW} / \mathrm{m}^{2}$, respectively [42]. On the other hand, tests carried out with a green roof installed on a school building in Athens have proved that the solution can significantly reduce the amount of the cool air used for air conditioning. Santamouris et al carrying out the tests observed that demand for cool air was reduced by 6 to $49 \%$ for the whole building and from 12 to $87 \%$ for the school's top floor [43].

Additionally, roofs covered with a layer of substrate and vegetation can reduce noise. Peck and Kuhn report that a $12 \mathrm{~cm}$ thick green roof can reduce noise level by as much as $40 \mathrm{~dB}$ [38]. In turn, Dunnett and Kingsbury in their tests carried out with a $10 \mathrm{~cm}$ thick green roof on an airport building in Germany, have observed a $5 \mathrm{~dB}$ noise reduction [44].

Another factors arguing for construction of green roofs include increasing prices of land and statutory requirements that oblige the investors to reconstruct the biologically active surface; in Poland, depending on the building type, such reconstruction should be carried out on $25 \div 30 \%$ of the building plot area [45]. Where a land plot is too small, introduction of vegetation onto roofs of buildings and underground car parks as well as balconies and terraces represents a favorable alternative. Such method of development of a roof can be also a good solution when construction of a new structure reduces surface of the existing green areas, raising thus the opposition among the local community [46].

Sustainable Urban Drainage Systems include also different installations for collecting and utilizing precipitation water in buildings. Such solutions not only reduce the volume of rainwater discharged from impervious areas to sewage systems, but allow also to decrease consumption of potable water. Nowadays, this is the issue of primary importance as global reserves of fresh waters permanently decrease. For this reason, alternative solutions are continuously sought after that would allow to limit exploitation of these resources by means of, among other things, collecting and utilizing rainwater. Installation of such systems in buildings is recommended by the European Commission [47].

Systems for harvesting precipitation water and using it for car wash, watering gardens, laundry, or flushing toilets are used for many years now in countries around the world [48-51]. Depending on the country, climatic conditions, and type of the building in which the rainwater utilization system is installed, reduction of demand for mains water can be as high as $60 \%$ [48].

Rainwater can be used for flushing toilets in dwelling houses [52-54], large sports facilities [55], university buildings [56] or supermarkets [57].

Ghisi and de Oliveira have carried out simulation studies on utilization of precipitation water for washing and toilet flushing in dwelling houses of southern Brazil. They analyzed two houses in which rainwater reservoirs with capacity of 3000 and $5000 \mathrm{dm}^{3}$ were installed. Reduction of demand for tap water in these buildings was 33.6 and $35.5 \%$, respectively [52]. Further, Fewkes has monitored, for a period of 12 months, a system collecting rainwater in a reservoir with capacity of $2000 \mathrm{dm}^{3}$ and supplying water for 
flushing toilets in a house in Nottingham, Great Britain. Depending on the season, economies in water consumption ranged from 4 to $100 \%$ [54]. Coombes et al have analyzed 27 houses in Newcastle, Australia. They found that rainwater could satisfy about $60 \%$ of water demand in these buildings [58]. Ghisi et al have carried out a scenario analysis concerning feasibility to utilize rainwater in dwelling houses of 62 towns of southern Brazil. They have found that, depending on the potable water consumption level, precipitation water could satisfy from 34 to $92 \%$ of the demand [59]. Palla et al have carried out model studies concerning optimum effectiveness of rainwater harvesting systems in three towns located in southern, central and northern Italy respectively, selected for significant differences in annual precipitation totals. In their analyses, the authors used archive data from a period of several decades. They have performed a scenario analysis taking into account not only 3 different precipitation regimes and 3 different potable water demand levels, but also rainwater storage reservoirs with capacities ranging from 2.5 to $400 \mathrm{~m}^{3}$. However, rainwater utilization in their studies was limited only to flushing toilets in residential buildings [60].

In Japan, three large sports facilities, namely Tokyo Dome, Fukuoka Dome, and Nagoya Dome were equipped with systems harvesting precipitation water used mainly for toilet flushing. In said facilities, water running off the roofs is collected in reservoirs with capacities of $1,000,1,800$ and $1,500 \mathrm{~m}^{3}$, respectively. Zaizen et al report that in the case of Fukuoka Dome, about $65 \%$ of demand for lower-quality water is fulfilled this way [55]. A system of the same type has been installed also at Kokugikan sports stadium in Tokyo. Rainwater from a reservoir with capacity of $750 \mathrm{~m}^{3}$ is used not only for flushing toilets but also as a medium in the cooling water system [48].

The Germany's largest rainwater harvesting system was constructed at the Frankfurt airport. From a roof with surface area of $26,800 \mathrm{~m}^{2}$, precipitation water is channeled to six tanks with capacity of $100 \mathrm{~m}^{3}$ allowing to save $1,000,000 \mathrm{~m}^{3}$ water annually as an average. The system is used mainly for flushing toilets and watering plants [61]. Similar rainwater utilization system installed in the Singapore airport enables to reduce the amount of water ranging from 28 to $33 \%$, resulting in annual savings of order of 304,200 \$ [61].

In Poland, systems using precipitation water for flushing toilets are still rare. Results of analyses aimed at feasibility of introducing such systems in dwelling houses were presented $e g$ in $[62,63]$.

\section{The LCC methodology}

The methodology consisting in determination of costs relating to existence of a facility as the so-called life cycle cost allows to carry out a comparative cost analysis for a determined time period with all economically important factors relating both to initial capital outlays and future operating costs taken into consideration. The method is very useful, among other things, in assessment of investment undertakings, as by comparing costs relating to different alternative solutions it is possible to select the most economic project option.

For each of the adopted precipitation water management variants and for the adopted investment duration period, LCC costs were determined from formula [63]: 


$$
L C C=K_{I}+\left[\sum_{t=1}^{T}(1+r)^{-t}\right] \cdot K_{E}
$$

where: $K_{I}$ - investment outlays [ ]; $K_{E}$ - operating costs [ ]; $T$ - LCC analysis duration period [years]; $r$ - fixed discount rate [-]; $t$ - consecutive year of operation of the facility [-].

\section{Model input data}

The LCC analysis of the rainwater management system was carried out for a multi-family building with the following parameters:

- number of floors: 4 ,

- number of stairwells: 2 ,

- number of residents: 70,

- $\quad$ roof surface area, $F=455 \mathrm{~m}^{2}$,

- $\quad$ average daily water demand for toilets flushing in the building: $2.45 \mathrm{~m}^{3} / \mathrm{d}$.

Calculations were performed with the use of Slys simulation model presented in details in papers $[62,63]$. In the calculations, archive data on daily precipitation levels were used gathered for a period of 10 years in the town of Rzeszow located in south-eastern part of Poland. The average annual precipitation for that period amounted to $612 \mathrm{~mm}$. For the purpose of LCC analysis, a 30-years long life cycle of the facility was assumed and a fixed discount rate $r=0.05$ [63].

\section{Variant I - Discharging precipitation water from building roof to the sewage system}

In Variant I it was assumed that precipitation water from roof will be discharged in full to the existing sewage system. The average coefficient of runoff from the roof slope $\psi=0.8$ was adopted for calculations.

In view of the fact that the investment cost analysis is focused on the point of view of the building user who does not incur financial outlays for development of sewerage network, the LCC analysis accounts in this case only for operating costs including fees for discharging precipitation water to sewage system.

Amount of the fee was determined in accordance with guidelines set out in the Ordinance of the Minister of Building Industry on determination of tariffs, template of application for tariff approval and conditions of settlements on account of water supply and collective sewage disposal [64]. According to the regulation, the fee charged for precipitation water disposal is calculated as the product of area of the surface from which water is discharged and the rate established for a given group of entities for $1 \mathrm{~m}^{2}$ of contaminated or paved surface or, where a measuring instrument is installed, the product of measured runoff volume and the rate established for a given group of entities for $1 \mathrm{~m}^{3}$ of the measured rainwater volume. The charging system is therefore similar to the methods adopted in other countries.

For the analyzed building, the fee rate amounting to 0.25 per year and square meter of the roof surface area was adopted. 


\section{Variant II - Retention of precipitation water on a green roof}

In Variant II, traditional roofing of the building is replaced with an extensive green roof with $10 \mathrm{~cm}$ thick substrate layer and vegetation of the stonecrop type. Extensive green roofs, in view of their low investment and operating costs, are used more frequently than intensive ones. In Germany, the country acknowledged as the most advances in the green roof technology, more than $80 \%$ of the systems installed are extensive ones [65]. In the year $2005,14 \%$ of surface area of all flat roofs in Germany was covered with vegetation [66].

It was assumed that the roof analyzed in Variant II had slope inclination of $2 \%$ and the structure of layers as shown in Figure 1.

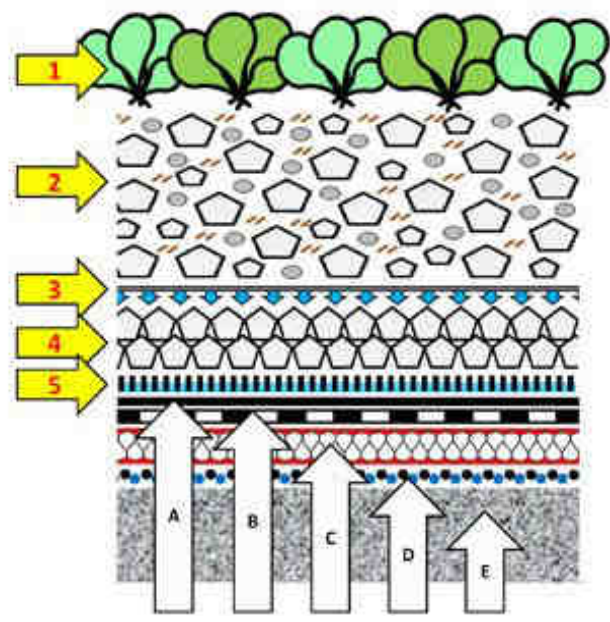

Fig. 1. Cross-section through the layers of the analyzed roof: 1 - extensive vegetation, 2 - growing medium, 3 - filter fabric, 4 - drainage layer, 5 - protection fabric, A - membrane, B - waterproofing membrane, C - thermal insulation, D - vapor barrier, E - supporting structure [67]

The cost of the implementation of extensive green roof

\begin{tabular}{|c|c|}
\hline Layer & $\begin{array}{c}\text { Unit price } \\
{\left[/ \mathbf{m}^{\mathbf{2}}\right]}\end{array}$ \\
\hline Extensive vegetation & 4.19 \\
\hline Roof substrate $10 \mathrm{~cm}$ & 5.14 \\
\hline Unwoven filtration geofabric & 2.61 \\
\hline Drainage layer of water-absorbing aggregates, 5 cm & 1.19 \\
\hline Absorbing-protecting unwoven geofabric PP & 1.98 \\
\hline Subtotal, materials & 15.11 \\
\hline Labor costs & 11.36 \\
\hline TOTAL & 26.47 \\
\hline
\end{tabular}

In the LCC analysis, the green roof construction cost (Table 1) was adopted according to the layered design presented in Figure 1.

The investment outlays do not include costs related to construction of a top floor ceiling with increased carrying capacity. This follows from the fact that the roof adopted for 
the analysis is a lightweight solution and for a building with surface area of $455 \mathrm{~m}^{2}$ any reinforcement of its structure is not necessary.

Maintenance of extensive roofs, after a period of acclimatization, is relatively easy. With the use of xerophilous vegetation such as stonecrops, sengreens or some mosses, the plants require little water. For that reason, on the grounds of analyses carried out for actually constructed and operated extensive green roofs, operating costs at the level of $0.23 / \mathrm{m}^{2} / \mathrm{yr}$ were adopted.

Apart from that, the cost was taken into account related to disposal of the excess rainwater impossible to store on the roof after reaching a maximum watering level. The quantity was calculated in a simulation model based on precipitation data for the period of 10 years. The average volume of rainwater discharged to sewage system was $16.31 \mathrm{~m}^{3} / \mathrm{yr}$. The costs related to discharging precipitation water was assumed as amounting to $0.68 / \mathrm{m}^{3}$.

\section{Variant III - Utilization of precipitation water for flushing toilets in the building}

In Variant III subject to the analysis, precipitation water will be channeled from roof to a reservoir installed in basement. Its volume, $V_{\mathrm{zb}}=22.5 \mathrm{~m}^{3}$, was determined based on demand of water for flushing toilets. The related water consumption was assessed as amounting on average to $30 \%$ of the whole water demand in a dwelling house $[68,69]$.

From the reservoir, water will be supplied to toilet bowls by means of a pumping system. In the case of the amount of water stored in the rainwater reservoir being insufficient, the tank will be supplied with tap water.

\section{Results}

In each of the variants, the amount of 5,114 was taken into account in the investment outlays representing the cost of construction of internal piping system supplying water for flushing toilets. Apart from this cost, investment outlays in Variant II include also the costs of construction of the extensive green roof (12,044 ), and in Variant III - the cost of the utility system utilizing precipitation water. Capital costs of this variant determined in the investment cost estimate amount to 16,990 .

Further, operating costs specific for each of the variants included the tap water purchase cost and fees for discharging wastewater to the sewage system. The following figures were used for calculations:

- $\quad$ tap water purchase price, $c_{w}=0.85 / \mathrm{m}^{3}$;

- $\quad$ sewage discharge price, $c_{s}=0.7 / \mathrm{m}^{3}$;

- volume of tap water supplied to toilets: $894.25 \mathrm{~m}^{3} / \mathrm{yr}$.

Summary of costs of the analyzed investment options

\begin{tabular}{|c|c|c|c|}
\hline $\begin{array}{c}\text { Precipitation water } \\
\text { management variant }\end{array}$ & $\begin{array}{c}\text { Investment costs } \\
{[]}\end{array}$ & $\begin{array}{c}\text { Operating costs } \\
{[]}\end{array}$ & $\begin{array}{c}\text { LCC } \\
[]]\end{array}$ \\
\hline Variant I & 05,114 & 22,930 & 28,044 \\
\hline Variant II & 17,158 & 21,514 & 38,672 \\
\hline Variant III & 22,113 & 20,420 & 42,533 \\
\hline
\end{tabular}


On the other hand, operating costs for Variant III include the price of electric energy used for pumping water to recipients from the rainwater storage reservoir $\left(c_{e}=0.13 / \mathrm{kWh}\right)$.

Results of the LCC analysis are presented in Table 2.

\section{Conclusions}

The LCC analysis carried out for different rainwater management variant applied in a multi-family dwelling building allows to formulate the following conclusions:

- The less LCC was obtained for the variant in which precipitation water from the roof is discharged directly to the sewage system. This follows from the fact that this variant does not require additional investment outlays incurred in Variants II and III. However, operating costs are highest in this case.

- Implementation of Variants II and III in the building in question is not profitable at the moment, therefore non-financial criteria must argue for these solutions, such as $e g$ environment protection aspects. Operational costs are only slightly lower that those in Variant I to a degree not compensating the incurred capital costs.

- Implementation of the system providing for commercial utilization of rainwater in the analyzed building is the most expensive, and economies resulting from replacing tap water with rainwater are small and have no effect on the overall profitability of the investment.

- From the point of view of environmental criteria, utilization of precipitation water in Variants II and III reduces the amount of water disposed to the sewage system and has a positive effect on the receiving water, ie typically surface waters. Moreover, green roofs absorb carbon dioxide, generate oxygen, and intercept dust and other pollutants.

- Variant II can additionally improve the overall economics of the building. Green roofs, thanks to their thermal insulation properties, have positive effect on microclimate inside the building. In summer they prevent overheating, reducing heat losses in cold seasons, thus contributing to reduction of energy consumption for heating and air conditioning. Further, according to numerous studies, green roofs are up to two times more durable than those covered with traditional roofing materials.

\section{References}

[1] EU Water Framework Directive (Directive 2000/60/EC of the European Parliament and of the Council of 23 October 2000 establishing a framework for Community action in the field of water policy, OJ L 327 , 22.12.2000, p. 1-73).

[2] Act of 18 July 2001 'Water Law'. J. Laws 2001, No. 115, Item 1229 as amended.

[3] Burszta-Adamiak E. Opłaty za wody opadowe - doświadczenia polskie i zagraniczne [Tariffs for precipitation water - domestic and foreign experiences]. Gaz Woda i Techn Sanit. 2009;3:15-18.

[4] http://www.ci.minneapolis.mn.us/stormwater/fee/stormwater_faq.asp

[5] Parikh P, Taylor M, Hoagland T, Thurston H, Shuster W. Application of market mechanisms and incentives to reduce stormwater runoff. An integrated hydrologic, economic and legal approach. Environ Sci Policy. 2005;8:133-144.

[6] http://www.pittks.org/index.aspx?NID=497

[7] http://www.uaoh.net/egov/docs/1318276268_794250.pdf

[8] http://www.nashville.gov/water/cwip/stormwater_fee.asp

[9] http://www.richmondgov.com/PublicUtilities/documents/stormwaterbrochure.pdf

[10] http://www.ebook-tipp.eu/regenwasserversickerung/regenwassergebuehr

[11] http://www.stadtdetmold.de/regenwassergebuehr.0.html 
[12] Edel R. Stormwater utility fees in Germany. Gaz Woda i Techn Sanit. 2009;3:18-21.

[13] Chouli E, Aftias E, Deutsch JC. Applying storm water management in Greek cities: learning from the European experience. Desalination. 2007;210:61-68.

[14] Herman R. Green roofs in Germany: Yesterday, today and tomorrow. Proc $1^{\text {st }}$ North American Green Roof Conference: Greening Rooftops for Sustainable Communities, Chicago, May 29-30, 2003. Toronto: The Cardinal Group; 2003.

[15] Commission of the European Communities. Communication from the commission to the council and the European Parliament on Thematic Strategy on the urban environment. Brussels: 2006.

[16] Lee A. Life cycle cost analysis - green roofs from an investment. Proc $2^{\text {nd }}$ North American Green Roof Conference: Greening Rooftops for Sustainable Communities, Portland, June 2-4, 2004. Toronto: The Cardinal Group; 2004.

[17] Carter T, Keeler A. Life-cycle cost-benefit analysis of extensive vegetated roof systems. J Environ Manage. 2008;87:50-363.

[18] Alcazar S, Bass B. Life cycle assessment of green roofs - case study of an eight-story residential building in Madrid and implications for green roof benefits. Proc $4^{\text {th }}$ North American Green Roof Conference: Greening Rooftops for Sustainable Communities, Boston, May 11-12, 2006. Toronto: The Cardinal Group; 2006.

[19] Kosareo L, Ries R. Life Cycle Assessment of a green roof in Pittsburgh. Proc $4^{\text {th }}$ North American Green Roof Conference: Greening Rooftops for Sustainable Communities, Boston, May 11-12, 2006. Toronto: The Cardinal Group; 2006.

[20] Getter K, Rowe B, Andresen J. Quantifying the effect of slope on extensive green roof stormwater retention. Ecol Eng. 2007;31:225-231.

[21] DeNardo JC, Jarrett AR, Manbeck HB, Beattie DJ, Berghage RD. Stormwater mitigation and surface temperature reduction by green roofs. Trans. ASABE. 2005;48(4):1491-1496.

[22] Liesecke HJ. Extensive begrünung bei 5 dachneigung. Stadt und Grün. 1999;48(5):337-346.

[23] Köhler M, Schmidt M. Langzeituntersuchungen an begrünten Dächern in Berlin. Dach+Grün. 1999;8:12-18.

[24] Schade C. Wasserrückhaltung und Abflußbeiwerte bei dünnschichtigen extensivbegrünungen. Stadt und Grün. 2000;49(2):95-100.

[25] VanWoert ND, Rowe DB, Andresen JA, Rugh CL, Fernandez RT, Xiao L. Green roof stormwater retention: effects of roof surface, slope and media depth. J Environ Qual. 2005;34(3):1036-1044.

[26] Villarreal EL, Bengtsson L. Response of a Sedum green roof to individual rain events. Ecol Eng. 2005;25(1):1-7.

[27] Kolb W. Good reasons for roof planting: Green roofs and rainwater. Acta Hort. 2004;643:295-300.

[28] Bengtsson L. Peak flows from thin sedum-moss roof. Nord Hydrol. 2005;36:269-280.

[29] Köhler M. Urban storm water management by extensive green roofs. Proc $38^{\text {th }}$ IFLA World Congress. Singapore: 2005;124-133.

[30] Burszta-Adamiak E. Retention of precipitation water on green roof in Wrocław conditions. Gaz Woda i Techn Sanit. 2010;3:21-24.

[31] Szajda E, Pływaczyk A, Pęczkowski G. Using green roofs for reduction of precipitation water runoff in municipal agglomerations. In: Precipitation water management problems. Łomotowski J, editor. Wrocław: 2008.

[32] Stec A, Hypiak J. Modelling rainwater runoff from green roofs in the Storm Water Management Model program. Instal. 2011;2:38-42.

[33] Liu K. Engineering performance of rooftop gardens through field evaluation. Proc $18^{\text {th }}$ International Convention of the Roof Consultants Institute. Tampa, FL: 2003;93-103.

[34] Fioretti R, Palla A, Lanza LG, Principia P. Green roof energy and water related performance in the Mediterranean climate. Build Environ. 2010;45:1890-1904.

[35] Moran A, Hunt B, Jennings G. A North Carolina field study to evaluate green roof runoff quantity, runoff quality and plant growth. Proc $2^{\text {nd }}$ North American Green Roof Conference: Greening Rooftops for Sustainable Communities, Portland, June 2-4, 2004. Toronto: The Cardinal Group; 2004.

[36] Deutsch B, Whitlow H, Sullivan M, Savineau M. A green roof vision based on environmental benefits for air quality and storm water management. Proc $3^{\text {rd }}$ North American Green Roof Conference: Greening Rooftops for Sustainable Communities, Washington, May 4-6, 2005. Toronto: The Cardinal Group; 2005.

[37] Peck S. A model for North American infrastructure development. EarthPledge. Green roofs: Ecological design and construction. Atglen: Schiffer Books, 2005;127-129.

[38] Peck S, Kuhn M. Design guidelines for green roofs. www. cmhc-schl.gc.ca, 16 Nov. 2005. 
[39] Yok Tan P, Sia A. A pilot green roof research project in Singapore. Proc $3^{\text {rd }}$ North American Green Roof Conference: Greening Rooftops for Sustainable Communities, Washington, May 4-6, 2005. Toronto: The Cardinal Group; 2005.

[40] Clark C, Talbot B, Bulkley J, Adriaens P. Optimization of green roofs for air pollution mitigation. Proc $3^{\text {rd }}$ North American Green Roof Conference: Greening Rooftops for Sustainable Communities, Washington, May 4-6, 2005. Toronto: The Cardinal Group; 2005.

[41] Peck S, Callaghan C, Kuhn M, Bass B. Greenbacks from green roofs: Forging a new industry in Canada. Ottawa: Canada Mortgage and Housing Corporation; 1999.

[42] Connelly M, Liu K. Green roof research in British Columbia: An overview. Proc $3^{\text {rd }}$ North American Green Roof Conference: Greening Rooftops for Sustainable Communities, Washington, May 4-6, 2005. Toronto: The Cardinal Group; 2005.

[43] Santamouris M, Pavlou C, Doukas P, Mihalakakou G, Synnefa A, et al. Investigationg and analyzing the energy and environmental performance of an experimental green roof system installed in a nursery school building in Athens. Energy, 2007;32:1781-1788.

[44] Dunnett N, Kingsbury N. Planting green roofs and living walls. Portland: Timber Press; 2004.

[45] Ordinance of the Minister of Infrastructure of 12 April 2002 on technical conditions applicable to buildings and location thereof. J Laws No. 75, Item 690.

[46] Loder M, Peck S. Green roofs contribution to smart growth implementation. Proc $2^{\text {nd }}$ North American Green Roof Conference: Greening Rooftops for Sustainable Communities, Portland, June 2-4, 2004. Toronto: The Cardinal Group; 2004.

[47] European Commission: Study on water performance of buildings. Reference Report 070307/2008/520703/ETU/D2, 2009.

[48] Furumai H. Rainwater and reclaimed wastewater for sustainable urban water use. Phys Chem Earth. 2008;33:340-346.

[49] Jones M, Hunt W. Performance of rainwater harvesting systems in the southeastern United States. Resour Conserv Recy. 2010;54:623-629.

[50] Coombes P. Rainwater Tanks Revisited: New opportunities for urban water cycle management. The University of Newcastle, Australia; 2003.

[51] Ghisi E, Tavares D, Rocha V. Rainwater harvesting in petrol stations in Brasilia: Potential for notable water savings and investment feasibility analysis. Resour Conserv Recy. 2009;54:79-85.

[52] Ghisi E, Oliveira S. Potential for potable water savings by combining the use of rainwater and greywater in houses in southern Brazil. Build Environ. 2007;42:1731-1742.

[53] Ghisi E. Potential for potable water savings by using rainwater in the residential sector of Brazil. Build Environ. 2006;41:1544-1550.

[54] Fewkes A. The use of rainwater for WC flushing: the field testing of a collection system. Build Environ. 1999;34:765-772.

[55] Zaizen M, Urakawa T, Matsumoto Y, Takai H. The collection of rainwater from dome stadiums in Japan. Urban Water. 1999;1:355-359.

[56] Appan A. A dual-mode system for harnessing roofwater for non-potable uses. Urban Water. 1999;1:317-321.

[57] Chilton J, Maidment G, Marriott D, Francis A, Tobias G. Case study of rainwater recovery system in a commercial building with a large roof. Urban Water. 1999;1:345-354.

[58] Coombes PJ, Argus JR, Kuczera G. Figtree place: a case study in water sensitive urban development. Urban Water. 1999;1:335-343.

[59] Ghisi E, Montibeller A, Schmidt RW. Potential for potable water savings by using rainwater: An analysis over 62 cities in southern Brazil. Build Environ. 2006;41:204-210.

[60] Palla A, Gnecco I, Lanza LG. Non-dimensional design parameters and performance assessment of rainwater harvesting systems. J Hydrol. 2011;401:65-76.

[61] www.rainwaterharvesting.org

[62] Słyś D. Potential of rainwater utilization in residential housing in Poland. Water Environ J. 2009;23:318-325.

[63] Słyś D, Bewszko T. LCC analysis of rainwater utilization system in multi-family residential buildings. Arch Environ Protect. 2010;4:107-118.

[64] Ordinance of the Minister of Building Industry on determination of tariffs, template of application for tariff approval and conditions of settlements on account of water supply and collective sewage disposal. J. Laws 2006, No. 127, Item 886. 
[65] Philippi P. How to get cost reduction in green roof construction. Proc $4^{\text {th }}$ Annual Greening Rooftops for Sustainable Communities, Boston, May 11-12, 2006. Toronto: The Cardinal Group; 2006.

[66] Köhler M, Keeley M. Green roof technology and development. EarthPledge. Green roofs: Ecological design and construction. Schiffer Books; Atglen: 2005, 108-112.

[67] www.dachyzielone.pl

[68] Campisano A, Modica C. Experimental investigation on water saving by the reuse of washbasin grey water for toilet flushing. Urban Water. 2010;7:17-24.

[69] Fewkes A. Modelling the performance of rainwater collection systems: towards a generalized approach. Urban Water. 2000;1:323-333.

\title{
ANALIZA LCC WARIANTÓW ZAGOSPODAROWANIA WÓD DESZCZOWYCH
}

\author{
${ }^{1}$ Katedra Infrastruktury i Ekorozwoju, Politechnika Rzeszowska im. I. Łukasiewicza
}

\begin{abstract}
Abstrakt: Przedstawiono wyniki analizy LCC dla kilku wariantów zagospodarowania wód opadowych dla projektowanego wielorodzinnego budynku mieszkalnego. Zgodnie z metodologią określania Life Cycle Cost wykonano obliczenia w pełnym cyklu istnienia przedsięwzięcia, uwzględniając zarówno nakłady inwestycyjne, jak i koszty użytkowania i konserwacji. Analiza LCC została przeprowadzona dla wariantu, w którym założono, że wody opadowe $\mathrm{z}$ dachu zostaną odprowadzone w całości do systemu kanalizacyjnego. Natomiast $\mathrm{w}$ drugim wariancie tradycyjny dach budynku został zastąpiony dachem zielonym. Tego typu obiekty dzięki swoim właściwościom retencyjnym mogą opóźniać spływ wód opadowych i redukować całkowity odpływ z powierzchni dachu, przez co zaliczane są do zrównoważonych systemów odwadniających (Sustainable Urban Drainage Systems). W trzecim przypadku zastosowano system gospodarczego wykorzystania wody deszczowej w budynku. Założono, że zmagazynowane w zbiorniku wody opadowe zostaną wykorzystane w instalacji sanitarnej do spłukiwania toalet, co pozwoli obniżyć koszty zakupu wody wodociągowej i wpłynie korzystanie na wyniki finansowe funkcjonowania obiektu mieszkalnego.
\end{abstract}

Słowa kluczowe: woda deszczowa, analiza LCC, rozwój zrównoważony 